\title{
Pivotal Role of Residual Coconut Water and Spent Wash on Phyllosphere and Rhizosphere Microflora of Gherkin (Cucumis sativus L) Under Glass House Condition
}

\author{
S. Umesha* and B. Narayanaswamy \\ Department of Agricultural Microbiology, UAS, GKVK, Bengaluru-65 \\ *Corresponding author
}

\begin{tabular}{|c|c|}
\hline & A B S T R A C T \\
\hline Keywords & \multirow{4}{*}{$\begin{array}{l}\text { Application of residual coconut water and spent wash obtained from desiccated } \\
\text { coconut mills has relatively enhanced the phyllosphere and rhizosphere microflora } \\
\text { of gherkin under glass house condition. Among the different concentrations of } \\
\text { residual coconut water and spent wash, the } 10 \text { per cent of spent wash showed } \\
\text { higher phyllosphere populations at } 45 \text { days after sowing, such as bacteria, yeast } \\
\text { and actinobacteria }\left(0.316,0.295 \text { and } 0.133 \times 10^{4} \mathrm{cfu} / \mathrm{cm}^{2}\right) \text { and rhizosphere } \\
\text { microflora viz., bacteria, fungi and actinobacteria }\left(58.33 \times 10^{5}, 10.80 \times 10^{4}, 14.00\right. \\
\times 10^{3} \mathrm{cfu} \mathrm{g}^{-1} \text { of soil) and beneficial microflora like Azotobacter sp, Phosphate } \\
\text { solubilizing bacteria and Pseudomonas sp. }\left(14.67,9.00 \text { and } 18.30 \times 10^{5} \mathrm{cfu} \mathrm{g}^{-1} \text { of }\right. \\
\text { soil) as compared to control. }\end{array}$} \\
\hline $\begin{array}{l}\text { Phyllosphere } \\
\text { and rhizosphere } \\
\text { microflora. }\end{array}$ & \\
\hline Article Info & \\
\hline $\begin{array}{l}\text { Accepted: } \\
\text { 29 June } 2017 \\
\text { Available Online: } \\
10 \text { July } 2017\end{array}$ & \\
\hline
\end{tabular}

\section{Introduction}

The epiphytic phyllosphere and rhizosphere harbours a diverse group of microorganisms including bacteria, fungi, yeasts, algae and in some situations protozoans and nematodes (Morris and Kinkel, 2002). These heterogeneous microbial populations have a vital effect on the crop improvement, as they are powerful forces for specific enzyme mediated fundamental metabolic processes (Ahmed and Kibret, 2014).

These microorganisms were exposed to rapidly fluctuating conditions such as temperature, water content, drought and exogenous application of nutrients (Hirano and Upper, 2000). The plant associated microbes were stimulated by application of exogenous nutrients like coconut water. The presence of carbohydrates, amino acids and organic acids in coconut water acts as nutrient source for microorganisms. The growth promoting substances like auxin content of coconut water stimulates the release of saccharides from the plant cell wall and microbes utilized these compounds (Goldberg, 1980, Van derwal and Leveau, 2011) and formation of root architecture and photosynthetic activity of plants. Due to this effect, the plant produces sugars, amino acids and other organic acids in the form of root exudates in the rhizosphere. These exudates favoured colonization of microorganisms in the rhizosphere (Farhatullah et al., 2007). 
The use of locally available inputs or other growth enhancing product like the coconut water needs to be given importance. It is rich with different nutrients, phytohormones, enzymes and minerals.

Residual coconut water and spent wash are available from desiccated coconut industries. It is organically rich and therefore may contribute pollution to our environment if allowed to stagnate in open or into water bodies. Coconut water can be used directly on plants as it serves as a nutrient and organic matter (Genaro, 2013). Therefore, present study was undertaken to determine the effect of residual coconut water and spent wash on epiphytic microflora of gherkin under greenhouse condition.

\section{Materials and Methods}

\section{Source of residual coconut water and spent wash}

The matured coconuts are used for production of desiccated coconut powder in coconut industry. The desiccated coconut industries discharge residual coconut water and which were collected at two different stages from Maruthi desiccated coconut mills at Kaidal gate, Tiptur taluk, Tumkur district.

\section{Stages of sampling}

\section{Stage-1}

Residual coconut water- this water was collected after nut breaking. It constitutes only coconut water.

\section{Stage-2}

Spent wash - this was collected after deshelled coconut pieces were washed (out let). This stage contains- residual coconut water, coconut milk and water used for washing the de-shelled coconut pieces.

\section{Details of pot experiments}

Pot culture experiment was conducted in the glass house at Department of Agricultural Microbiology, UAS, GKVK, Bengaluru. Ajax variety of Gherkin (procured from the Nunhem's Pro Agro seeds Pvt. Ltd. Bengaluru) cultivar was used in the study. The crop was sown on $25^{\text {th }}$ January, 2015 and crop was maintained up to 45 days. Freshly collected residual coconut water and spent wash were sprayed at different intervals at 15 and 30 days after sowing. The initial chemical and biological properties and the average values along with methods followed are provided in table 1 .

\section{Experimental design and treatment details for pot experiment study}

The experiment had seven treatments with three replications, laid out in completely randomized block design and the treatments are as follows,

$\mathrm{T}_{1}$ : Control (water spray only)

$\mathrm{T}_{2}: 10 \%$ - Residual coconut water

$\mathrm{T}_{3}: 15 \%$ - Residual coconut water

$\mathrm{T}_{4}: 20 \%$ - Residual coconut water

$\mathrm{T}_{5}: 10 \%$ - Spent wash

$\mathrm{T}_{6}: 15 \%$ - Spent wash

$\mathrm{T}_{7}: 20 \%$ - Spent wash

\section{Isolation of phyllosphere microorganisms}

The phyllosphere microorganisms were isolated from gherkin leaves at different intervals. The leaf samples were collected from each treatment at regular interval and kept in the sterile polythene cover and then brought to the laboratory in the icebox and samples were analyzed within $24 \mathrm{hrs}$. The leaf of all ages was cut randomly into a $10 \mathrm{~mm}$ disc and 30 leaf discs were placed in $100 \mathrm{ml}$ sterile water blank and shaken for 20 minutes in a rotatory shaker at $100 \mathrm{rpm}$. After 
shaking, the $10 \mathrm{ml}$ of suspension was taken and transferred to $90 \mathrm{ml}$ sterile water blank and shaken for few seconds. Sample $(1 \mathrm{ml})$ from $90 \mathrm{ml}$ was transferred to $9 \mathrm{ml}$ sterile water blank $\left(10^{2}\right)$ and serially diluted up to $10^{4}$ dilution. The microorganisms viz., bacteria, yeast and actinomycetes were isolated using a spread plate technique by plating on specific nutrient media and plates were incubated at $30 \pm 1{ }^{0} \mathrm{C}$ for a week the colonies which emerged were counted (Aneja, 2003).

\section{Enumeration of rhizosphere microorganisms}

The population of rhizosphere microorganisms in soil was determined by serial dilution plate count method. Rhizosphere soil samples were collected treatment wise at different intervals. Ten grams of soil (treatment wise) weighed and mixed in $90 \mathrm{ml}$ sterilized water blank to give $10^{1}$ dilutions. Subsequent dilutions up to $10^{5}$ were made by transferring serially $1 \mathrm{ml}$ of each dilution to $9 \mathrm{ml}$ sterilized water blanks. The population of bacteria, fungi, actinomycetes, Azotobacter sp., Pseudomonas sp. and phosphate solubilizing bacteria were determined in respective medium. Plates were incubated at $30 \pm 1^{0} \mathrm{C}$ for a week and the colonies which emerged were counted.

\section{Results and Discussion}

The phyllosphere microorganisms of gherkin such as bacteria, yeast and actinobacteria were significantly influenced by the foliar application of residual coconut water and spent wash at different intervals and the results are presented in table 2. Before spraying (15 days after sowing), the bacteria, yeast and actinobacteria recorded maximum (0.106, 0.106, $\left.0.045 \times 10^{4} \mathrm{cfu} \mathrm{cm}^{2}\right)$ and minimum $\left(0.064,0.064,0.020 \times 10^{4} \mathrm{cfu} \mathrm{cm}^{2}\right)$. However, at 30 days after sowing there was significant difference between the populations among the treatments. Higher bacterial, yeast and actinobacterial populations were recorded at foliar application of 10 per cent spent wash $\left(0.209,0.290\right.$ and $\left.0.063 \times 10^{4} \mathrm{cfu}^{\mathrm{cm}^{2}}\right)$. A similar trend was observed at 45 days after sowing. Higher bacterial, yeast and actinobacterial populations were found in the treatment at 10 per cent spent wash $(0.316$, 0.295 and $0.113 \times 10^{4} \mathrm{cfu}^{\mathrm{cm}^{2}}$ ) compared to control.

The proliferation of phyllosphere microorganisms at all the stages of crop growth was maximum in treatment at 10 per cent residual coconut milk. This may be because coconut water consists of considerable amounts of sugars, amino acids, mineral salts, vitamin B complex, vitamin $\mathrm{C}$ and cytokines etc. Microorganisms require a source of carbon and nitrogen for maintenance and growth, all these are present in coconut water (Vigliar et al., (2006), Mishra and Srivastava (1974), Chikere and Azubuike (2014) and Shannon et al., (2008).

The rhizosphere microflora of gherkin was significantly influenced by the foliar application of residual coconut water and spent wash at different intervals and the results are presented in tables 3 and 4 . Bacterial population at15 DAS (before spraying) the bacterial population in rhizosphere was 18.33 to $20.33 \times 10^{5} \mathrm{cfu} \mathrm{g}^{-1}$ of soil. However, higher bacterial population in rhizosphere at 30 and 45 DAS was recorded in the treatment 10 per cent spent wash (42.00 and $58.33 \times 10^{5} \mathrm{cfu} \mathrm{g}^{-1}$ of soil). Whereas, the fungal populationat $15 \mathrm{DAS}$, the fungal population in rhizosphere ranged from 2.33 to $3.70 \times 10^{4} \mathrm{cfu} \mathrm{g}^{-1}$ of soil and at 30 and 45 DAS the higher fungal population was recorded in 10 per cent spent wash (11.30 and $10.80 \times 10^{4} \mathrm{cfu} \mathrm{g}^{-1}$ of soil respectively) and rest of the treatments differed significantly. Similarly actinobacteria population at 15 DAS in rhizosphere of gherkin ranged from 1.67 to $3.60 \times 10^{3} \mathrm{cfu} \mathrm{g}^{-1}$ of soil. At 30 and 45 DAS, 
application of 10 per cent spent wash recorded significantly higher $(12.63$ and 14.00 $\mathrm{x} 10^{3}$ cfu $\mathrm{g}^{-1}$ of soil respectively) actinobacteria population and lower actinobacteria population was recorded with the application of 10 per cent residual coconut water $\left(6.33\right.$ and $8.60 \times 10^{3} \mathrm{cfu} \mathrm{g}^{-1}$ of soil, respectively). The Azotobacter population in rhizosphere of gherkin before spraying (15 DAS) ranged from 3.00 to $3.67 \times 10^{5} \mathrm{cfu} \mathrm{g}^{-1}$ of soil. Whereas at 30 and 45 DAS higher Azotobacter population in rhizosphere was recorded in the treatment 10 per cent spent wash (10.00 and $14.67 \times 10^{5} \mathrm{cfu} \mathrm{g}^{-1}$ of soil).
The Pseudomonas population in rhizosphere of gherkin before spraying (15 DAS) ranged from 2.00 to $3.03 \times 10^{5} \mathrm{cfu} \mathrm{g}^{-1}$ of soil and at 30 and 45 DAS was Pseudomonas population was significantly higher in treatment 10 per cent spent wash $\left(16.70\right.$ and $17.23 \times 10^{5} \mathrm{cfu} \mathrm{g}^{-1}$ of soil) Phosphate solubilizing bacterial (PSB) population before spraying (15 DAS) the phosphate solubilizing bacterial population ranged from 1.00 to $2.13 \times 10^{5} \mathrm{cfu} \mathrm{g}^{-1}$ of soil. Whereas, at 30 and $45 \mathrm{DAS}$, the maximum phosphate solubilizing bacteria ( 8.33 and 9.00 $\mathrm{x} 10^{5} \mathrm{cfu} \mathrm{g}^{-1}$ of soil) was observed in treatment 10 per cent spent wash.

Table.1 Initial chemical and biological properties of soil used for pot experiment

\begin{tabular}{|c|c|c|c|}
\hline Sl. No. & \begin{tabular}{|l} 
Particulars \\
\end{tabular} & Value & Method employed \\
\hline \multicolumn{4}{|c|}{ Chemical properties } \\
\hline 1 & $\mathrm{pH}$ & 6.73 & Potentiometry (Piper, 1996) \\
\hline 2 & $\mathrm{EC}\left(\mathrm{dSm}^{-1}\right)$ & 0.12 & Conductometry (Jackson, 1973) \\
\hline 3 & Organic carbon $(\%)$ & 0.41 & $\begin{array}{l}\text { Wet oxidation titrimetry (Walkey } \\
\text { and Black, 1934) }\end{array}$ \\
\hline 4 & Available $\mathrm{N}\left(\mathrm{kg} \mathrm{ha}^{-1}\right)$ & 336.17 & $\begin{array}{l}\text { Alkaline permanganate digestion } \\
\text { and distillation (Subbaiah and } \\
\text { Asija, 1956) }\end{array}$ \\
\hline 5 & Available $\mathrm{P}_{2} \mathrm{O}_{5}\left(\mathrm{~kg} \mathrm{ha}^{-1}\right)$ & 31.20 & $\begin{array}{l}\text { Spectrophotometry (Jackson, } \\
\text { 1973) }\end{array}$ \\
\hline 6 & Available $\mathrm{K}_{2} \mathrm{O}\left(\mathrm{kg} \mathrm{ha}^{-1}\right)$ & 195.30 & $\begin{array}{l}\text { Flame photometry (Jackson, } \\
\text { 1973) }\end{array}$ \\
\hline \multicolumn{4}{|c|}{ Biological properties } \\
\hline 7 & Bacteria & $\begin{array}{c}16 \times 10^{5} \\
\text { cfu g }^{-1} \text { soil }\end{array}$ & \multirow{6}{*}{$\begin{array}{l}\text { Serial dilution plate count } \\
\text { technique } \\
\text { (Bunt and Rovira, 1955) }\end{array}$} \\
\hline 8 & Fungi & $\begin{array}{c}5 \times 10^{4} \\
\text { cfu g }^{-1} \text { soil }\end{array}$ & \\
\hline 9 & Actinomycetes & $\begin{array}{c}7 \times 10^{3} \\
\text { cfu g }^{-1} \text { soil }\end{array}$ & \\
\hline 10 & Azotobacter sp. & $\begin{array}{c}6 \times 10^{5} \\
\text { cfu g }^{-1} \text { soil }\end{array}$ & \\
\hline 11 & Pseudomonas sp. & $\begin{array}{c}8 \times 10^{5} \\
\text { cfu g }^{-1} \text { soil }\end{array}$ & \\
\hline 12 & P solubilizing bacteria & $\begin{array}{c}5 \times 10^{5} \\
\text { cfu g }^{-1} \text { soil }\end{array}$ & \\
\hline
\end{tabular}


Table.2 Effect of residual coconut water and spent wash on phyllosphere microflora of gherkin under glass house condition

\begin{tabular}{|c|c|c|c|c|c|c|c|c|c|}
\hline \multirow{4}{*}{ Treatments } & \multicolumn{3}{|c|}{ Bacteria } & \multicolumn{3}{|c|}{ Yeast } & \multicolumn{3}{|c|}{ Actinobacteria } \\
\hline & \multicolumn{9}{|c|}{$10^{4} \mathrm{cfu} / \mathrm{cm}^{2}$} \\
\hline & $\mathrm{BS}$ & \multicolumn{2}{|c|}{$\mathrm{AS}$} & $\mathrm{BS}$ & \multicolumn{2}{|c|}{$\mathrm{AS}$} & $\mathrm{BS}$ & \multicolumn{2}{|c|}{ AS } \\
\hline & $\begin{array}{c}15 \\
\text { DAS }\end{array}$ & $\begin{array}{c}30 \\
\text { DAS }\end{array}$ & $\begin{array}{c}45 \\
\text { DAS }\end{array}$ & $\begin{array}{c}15 \\
\text { DAS }\end{array}$ & $\begin{array}{c}\text { 30 } \\
\text { DAS }\end{array}$ & $\begin{array}{c}45 \\
\text { DAS }\end{array}$ & $\begin{array}{c}15 \\
\text { DAS }\end{array}$ & $\begin{array}{c}\text { 30 } \\
\text { DAS }\end{array}$ & $\begin{array}{c}45 \\
\text { DAS }\end{array}$ \\
\hline $\mathbf{T}_{\mathbf{1}}$ : Control (water spray) & 0.106 & 0.144 & 0.153 & 0.064 & 0.116 & 0.140 & 0.020 & 0.025 & 0.031 \\
\hline $\mathbf{T}_{2}: 10 \%$ - Residual coconut water & 0.103 & 0.188 & 0.266 & 0.078 & 0.278 & 0.287 & 0.034 & 0.049 & 0.106 \\
\hline $\mathbf{T}_{3}: 15 \%$ - Residual coconut water & 0.099 & 0.161 & 0.205 & 0.085 & 0.251 & 0.263 & 0.033 & 0.040 & 0.080 \\
\hline $\mathbf{T}_{\mathbf{4}}: 20 \%$ - Residual coconut water & 0.092 & 0.115 & 0.177 & 0.092 & 0.203 & 0.241 & 0.026 & 0.032 & 0.071 \\
\hline $\mathbf{T}_{\mathbf{5}}: 10 \%-$ Spent wash & 0.085 & 0.209 & 0.316 & 0.106 & 0.290 & 0.295 & 0.045 & 0.063 & 0.113 \\
\hline $\mathbf{T}_{6}: 15 \%-$ Spent wash & 0.064 & 0.173 & 0.238 & 0.113 & 0.262 & 0.271 & 0.032 & 0.044 & 0.094 \\
\hline $\mathbf{T}_{7:} 20 \%-$ Spent wash & 0.067 & 0.154 & 0.191 & 0.099 & 0.214 & 0.250 & 0.030 & 0.036 & 0.076 \\
\hline $\begin{array}{l}\text { S. Em. } \pm \\
\text { C. D. at } 1 \%\end{array}$ & NS & $\begin{array}{l}0.43 \\
1.32\end{array}$ & $\begin{array}{l}0.42 \\
1.30\end{array}$ & NS & $\begin{array}{l}0.33 \\
1.01 \\
\end{array}$ & $\begin{array}{l}0.41 \\
1.25\end{array}$ & NS & $\begin{array}{l}0.49 \\
1.49\end{array}$ & $\begin{array}{l}0.36 \\
1.10 \\
\end{array}$ \\
\hline
\end{tabular}

Table.3 Effect of residual coconut water and spent wash on rhizosphere microorganisms of gherkin under glass house condition

\begin{tabular}{|c|c|c|c|c|c|c|c|c|c|}
\hline \multirow{3}{*}{ Treatments } & \multicolumn{3}{|c|}{$\begin{array}{c}\text { Bacteria } \\
\left(10^{5}\right) \text { cfu g }^{-1} \text { of soil }\end{array}$} & \multicolumn{3}{|c|}{$\begin{array}{c}\text { Fungi } \\
\left(10^{4}\right) \mathrm{cfu}^{-1} \text { of soil }\end{array}$} & \multicolumn{3}{|c|}{$\begin{array}{c}\text { Actinobacteria } \\
\left(\mathbf{1 0}^{3}\right) \text { cfu }^{-1} \text { of soil }\end{array}$} \\
\hline & \multirow{2}{*}{$\frac{\text { BS }}{15 \text { DAS }}$} & \multicolumn{2}{|c|}{$\mathrm{AS}$} & \multirow{2}{*}{$\begin{array}{c}\text { BS } \\
15 \text { DAS }\end{array}$} & \multicolumn{2}{|c|}{ AS } & \multirow{2}{*}{$\frac{\mathrm{BS}}{15 \mathrm{DAS}}$} & \multicolumn{2}{|c|}{$\mathrm{AS}$} \\
\hline & & 30 DAS & 45 DAS & & 30 DAS & 45 DAS & & 30 DAS & 45 DAS \\
\hline $\mathbf{T}_{\mathbf{1}}$ : Control (water spray) & 19.00 & 32.32 & 43.67 & 2.33 & 8.33 & 10.60 & 1.67 & 9.00 & 10.60 \\
\hline $\mathbf{T}_{\mathbf{2}}: 10 \%$ - Residual coconut water & 18.33 & 24.73 & 31.80 & 3.00 & 5.03 & 4.00 & 3.00 & 6.33 & 8.60 \\
\hline $\mathbf{T}_{\mathbf{3}}: 15 \%$ - Residual coconut water & 18.67 & 28.67 & 36.70 & 3.70 & 6.00 & 5.62 & 3.60 & 7.40 & 9.33 \\
\hline $\mathbf{T}_{4}: 20 \%$ - Residual coconut water & 19.63 & 38.60 & 55.30 & 3.33 & 9.70 & 8.90 & 3.33 & 10.90 & 12.67 \\
\hline $\mathbf{T}_{\mathbf{5}}: 10 \%-$ Spent wash & 18.60 & 42.00 & 58.33 & 3.30 & 11.30 & 10.80 & 3.30 & 12.63 & 14.00 \\
\hline $\mathbf{T}_{6}: 15 \%-$ Spent wash & 18.67 & 32.03 & 40.50 & 3.00 & 7.67 & 6.10 & 3.00 & 8.03 & 10.00 \\
\hline $\mathbf{T}_{7:} 20 \%-$ Spent wash & 20.33 & 26.50 & 33.10 & 2.33 & 5.60 & 4.30 & 2.33 & 7.17 & 9.03 \\
\hline $\begin{array}{l}\text { S. Em. } \pm \\
\text { C. D. at } 1 \%\end{array}$ & NS & $\begin{array}{l}0.95 \\
2.88\end{array}$ & $\begin{array}{l}1.02 \\
3.10\end{array}$ & NS & $\begin{array}{l}\mathbf{0 . 4 3} \\
1.32\end{array}$ & $\begin{array}{l}0.33 \\
1.01\end{array}$ & NS & $\begin{array}{l}0.37 \\
1.14\end{array}$ & $\begin{array}{l}0.30 \\
0.93\end{array}$ \\
\hline
\end{tabular}


Table.4 Effect of residual coconut water and spent wash on beneficial microorganisms in rhizosphere of gherkin under glass house condition

\begin{tabular}{|c|c|c|c|c|c|c|c|c|c|}
\hline \multirow{3}{*}{ Treatments } & \multicolumn{3}{|c|}{$\begin{array}{l}\text { Azotobacter sp. } \\
\left(10^{5}\right) \text { cfu g }^{-1} \text { of soil }\end{array}$} & \multicolumn{3}{|c|}{$\begin{array}{l}\text { Phosphate solubilizing bacteria } \\
\left(\mathbf{1 0}^{5}\right) \mathrm{cfu}^{-1} \text { of soil }\end{array}$} & \multicolumn{3}{|c|}{$\begin{array}{l}\text { Pseudomonas sp. } \\
\left(10^{5}\right) \mathrm{cfu}^{-1} \text { of soil }\end{array}$} \\
\hline & \multirow{2}{*}{$\frac{\mathrm{BS}}{15 \mathrm{DAS}}$} & \multicolumn{2}{|c|}{ AS } & \multirow{2}{*}{$\frac{\mathrm{BS}}{15 \text { DAS }}$} & \multicolumn{2}{|c|}{ AS } & \multirow{2}{*}{$\frac{\mathrm{BS}}{15 \text { DAS }}$} & \multicolumn{2}{|c|}{$\mathrm{AS}$} \\
\hline & & 30 DAS & 45 DAS & & 30 DAS & 45 DAS & & 30 DAS & 45 DAS \\
\hline $\mathbf{T}_{\mathbf{1}}$ : Control (water spray) & 3.03 & 6.67 & 9.00 & 1.30 & 6.00 & 8.03 & 2.67 & 10.60 & 14.50 \\
\hline $\mathbf{T}_{2}: 10 \%$ - Residual coconut water & 3.00 & 4.33 & 5.60 & 1.67 & 2.33 & 4.30 & 2.00 & 8.10 & 10.40 \\
\hline $\mathbf{T}_{3}: 15 \%$ - Residual coconut water & 3.60 & 5.30 & 6.33 & 1.00 & 3.50 & 7.20 & 2.50 & 9.00 & 11.00 \\
\hline $\mathbf{T}_{4}: 20 \%$ - Residual coconut water & 3.33 & 8.90 & 14.03 & 2.00 & 6.60 & 8.40 & 3.03 & 14.33 & 17.23 \\
\hline $\mathbf{T}_{\mathbf{5}}: 10 \%-$ Spent wash & 3.67 & 10.00 & 14.67 & 1.33 & 8.33 & 9.00 & 2.33 & 16.70 & 18.30 \\
\hline $\mathbf{T}_{6}: 15 \%-$ Spent wash & 3.50 & 6.33 & 8.10 & 1.50 & 4.67 & 7.90 & 2.00 & 9.63 & 12.13 \\
\hline $\mathbf{T}_{7:} 20 \%-$ Spent wash & 3.33 & 5.07 & 7.00 & 2.13 & 3.00 & 6.33 & 2.30 & 8.60 & 10.90 \\
\hline $\begin{array}{l}\text { S. Em. } \pm \\
\text { C. D. at } 1 \%\end{array}$ & NS & $\begin{array}{l}0.30 \\
0.93\end{array}$ & $\begin{array}{l}0.25 \\
0.76\end{array}$ & NS & $\begin{array}{l}0.24 \\
0.79\end{array}$ & $\begin{array}{l}0.21 \\
0.66\end{array}$ & NS & $\begin{array}{l}0.37 \\
1.14\end{array}$ & $\begin{array}{l}0.41 \\
1.26\end{array}$ \\
\hline
\end{tabular}


The rhizosphere microorganisms recorded maximum in treatment 10 per cent spent wash and was on par with 20 per cent residual coconut water. These results are in line with the findings of Kiran et al., (2015), who pointed out that organic manures not only help to supply nutrients but also act as a food for microorganisms and encourage the multiplication of their population. The foliar spray of coconut milk to the crop will enhance the photosynthetic activity of plant. It will alter the plant root architecture and enhance the root exudates in the rhizosphere environment reported by Caers and Vending (S1986).

The fungal population decreased at 45 DAS in coconut water treated pots, it is possible that fungi did not react as fast as bacteria to the addition of $\mathrm{C}$ substrates with the organic fertilizers. It has also been observed that bacterial proliferation after the addition of labile organic substrates had antagonistic effects on fungal growth (Meidute et al., 2008).

In conclusion the study shown that epiphytic (phyllosphere and rhizosphere) microflora of gherkin has been enhanced by the application of residual coconut water as well as spent wash.

\section{References}

Ahemad, M. and Kibret, M. 2014. Mechanisms and applications of plant growth promoting rhizobacteria, current perspective. J. King Saud. Univ. Sci., 26: $1-20$.

Aneja, K.R. 2003. Staining and biochemical techniques. Edition $4^{\text {th }}$, Experiments in Microbiol. Plant Pathol. Biotechnol., 97-128.

Bunt, J.S. and Rovira, A.D. 1955. Microbiological studies of subantartic soil. J. Soil Sci., 6: 119-122.
Caers, M. and Vending, J.C. 1986. Benzyl adenine effects on the development of the photosynthetic apparatus in Zea mays, studies on photosynthetic activity, enzymes and chloroplast ultrastructure. Physiol. Plant, 66: 685-691.

Chikere, C.B. and Azubuike, C.C. 2014. Microbial composition of guava, hibiscus, mango and pumkin phyllosphere. African J. Biotechnol., 13(18): 1859-1866.

Farhatullah, Abbas, Z. and Abbas, S.J. 2007. In vitro effects of gibberellic acid on morphogenesis of potato explant. Inter. J. Agricul. Biol., 1: 181-182.

Genaro, D.O. 2013. Growth and yield of selected vegetables sprayed with mature coconut water. Inter. Sci. Res. J., 5(3): 96-106.

Goldberg, R. 1980. Cell wall polysaccharides activities and growth processes, a possible relationship. Physiol. Plant, 50: 261-264.

Hirano, S.S. and Upper, C.D. 2000. Bacteria in the leaf ecosystem with emphasis on Pseudomonas syringaea pathogen, ice nucleus and epiphyte. Microbiol. Mol. Biol. Rev., 64: 624-653.

Jackson, M.L. 1973. Soil chemical analysis, Prentice Hall India Pvt. Ltd., New Delhi.

Kiran, Satyanarayana, R., Vivekananda, R. and Shubha, S. 2015. Effect of nutrient management practices through organics on soil biological properties in organic chickpea (Cicer arietinum L.) cultivation under rainfed condition. Inter. Quar. J. Environ. Sci., 7: 183187.

Meidute, S., Demoling, F. and Baath, E. 2008. Antagonistic and synergistic effects of fungal and bacterial growth in soil after adding different carbon and nitrogen sources. Soil Biol. Biochem., 40: 23342343.

Mishra, R.R. and Srivastava, V.B. 1974. Leaf 
surface microflora of Hordium vulgare L. Acta Soc. Botani. Pol., 43: 207-212.

Morris, C.E. and Kinkel, L.L. 2002. Fifty years of phyllosphere microbiology significant contribution to research in related fields. Appl. Environ. Microbiol., 69: 340-350.

Piper, C.S. 1966. Soil and plant analysis, Academic Press, New York.

Shannon, N.S., Leon, L.B. and James, W.B. 2008. The influence of exogenous nutrients on the abundance of yeasts on the phylloplane of tufgrass. Microbiol. Ecol., 55(1): 15-20.

Subbaiah, B.Y. and Asija, G.L. 1956. A rapid procedure for the estimation of available nitrogen in soils. Curr. Sci.,
25: 259-260.

Van Der Wal, A. and Leveau, J.H. 2011. Modelling sugar diffusion across plant leaf cuticles, the effect of free water on substrate availability to phyllosphere bacteria. Environ. Microbiol., 13: 792797.

Vigliar, R., Sdepanian, V.L. and Fagundes, N.U. 2006. Biochemical profile of coconut water from coconut palms planted in an inland region. J. Pediatr., 82: 308-312.

Walkley, A.J. and Black, C.A. 1934. An examination of the method for determining soil organic matter and a proposed modification of the chromic acid titration. Soil Sci., 37: 28-29.

\section{How to cite this article:}

Umesha, S. and Narayanaswamy, B. 2017. Pivotal Role of Residual Coconut Water and Spent Wash on Phyllosphere and Rhizosphere Microflora of Gherkin (Cucumissativus L) Under Glass House Condition. Int.J.Curr.Microbiol.App.Sci. 6(7): 3956-3963. doi: https://doi.org/10.20546/ijcmas.2017.607.408 